\title{
Servant Leadership of School Administrators: Proposed Servant Leadership Training Program
}

\author{
Mauro Allan P. Amparado \\ Director, Community Awareness, Relations \& Extension Services \\ mapamparado@gmail.com \\ Carmen P. Villarante \\ Dean, College of Nursing \\ University of Cebu Lapu-Lapu and Mandaue, \\ Mandaue City, Cebu, Philippines
}

\section{Abstract}

The study determined the Servant Leadership of School Administrators of a University, the findings served as basis for a proposed Servant Leadership Training Program. This study was conducted in University of Cebu Lapu-Lapu and Mandaue, Mandaue City, Cebu, Philippines. The researchers measured the servant leadership of school administrators as perceived by faculty members and non-teaching staff. This study utilized the 42 items of the Servant Leadership Assessment Instrument (SLAl) by Dennis and Bocarnea to measure the extent to which a leader possessed five of these servant leader constructs using a seven-point Likert scale. Statistical treatment used were Simple percentage and Weighted Mean.

Findings revealed that the respondents agree (5.52) that the school administrators are exhibiting servant leadership. The top three indicators with the highest means were: My leader shows trustworthiness in me by being open to receive inputs from me (5.76); My leader creates a culture that fosters high standards of ethics (5.75); and My leader empowers me with opportunities so that I develop my skills (5.75). 
Out of the 42 indicators, this study shows that there are three indicators which are categorized as tend to agree: My leader is not interested in self-glorification (5.06); My leader has endured hardships, e.g. political, "turf wars," etc. to defend me (5.08); and My leader has made personal sacrifice/s for me (5.10).

The other indicators which have low means includes: My leader does not center attention on his or her own accomplishments (5.33); My leader trusts me to keep a secret (5.33); My leader knows I am above corruption (5.35); My leader has made sacrifices in helping others (5.37); My leader seeks to instill trust rather than fear of insecurity (5.37); My leader aspires not to be served but to serve others (5.39); My leader has asked me what I think the future direction will be (5.39).

Keywords: Servant Leadership; Ethics; Trustworthiness; Empowerment; Mandaue City, Cebu, Philippines

Recommended citation: Amparado, M. A. P. \& Villarante, C. P. (2019). Servant Leadership of School Administrators: Proposed Servant Leadership Training Program. Cebu Journal of Nursing, 2(1), 87-100.

\section{Introduction}

Managers need to start relinquishing their roles of judge and critic and begin viewing themselves as partners with employees. They still need to communicate a direction for their unit, help set challenging goals, and monitor resources. But their new role invites them to view themselves as stewards of a broad range of human and technical resources. This stewardship paradigm shifts their emphasis from direction and control to that of servant leadership, where their challenge is to help others attain relevant goals while developing their skills and abilities. The essence of 
servant leadership is placing the needs of others above one's own self-interest. The goal is to help others develop their talents fully, make meaningful contributions, and succeed. To accomplish this, servant leaders strive to exhibit several key behaviors: they listen actively and empathetically; they engage in introspection to understand better their own attitudes and feelings; they treat others with respect, as equals; they seek to engage in dialogue and often paraphrase to ensure understanding; they affirm the worth and contributions of each participant; they are willing to admit mistakes and ask for help; and they build trust by articulating their values and acting consistently with them (Newstrom, 2007).

Servant leadership is anchored in the human drive to bond with others and contribute to the betterment of the society. An emphasis on service motivation, as demonstrated by empowering and developing people with empathy and humility, differentiates servant leadership from other leadership frameworks (Mittal \& Dorfman, 2012).

The belief that some leadership style will always be effective regardless of the situation may not be true. Leadership may not always be important. Data from numerous studies indicate that, in many situations, any behaviors a leader exhibits are irrelevant. In other words, certain individual, job, and organizational variables can act as "substitutes for leadership," negating the influence of the leader. For instance, characteristics of subordinates such as experience, training, "professional" orientation, or need for independence can neutralize the effect of leadership. These characteristics can replace the subordinate's need for a leader's support or ability to create structure and reduce task ambiguity. Similarly, jobs that are inherently unambiguous and routine or that are intrinsically satisfying may place fewer demands on the leadership variable. Finally, such organizational characteristics as explicit formalized goals, rigid rules and procedures, or cohesive work groups can act in the place of formal leadership (Robbins \& 
Coulter).

\section{Related Studies}

When it comes to managing workers, results from hundreds of studies support several conclusions. First, in terms of style, female leaders are more likely than male leaders to (a) appeal to worker's pride and need for respect, (b) rely on emotional appeals to inspire motivation, (c) provide more of an intellectual basis for their decisions, (d) give more individual consideration to employees (as opposed to relying on policies), and (e) apply performance-contingent rewards and bonuses. Studies show male leaders on the other hand are much less active leaders and are more likely to (a) lead by exception, that is, step in only when something goes wrong or (b) demonstrate laissez-faire tactics or a hands-off approach to management. In terms of results, the more active role of the female leaders results in employees who are (a) more likely to report putting forth extra effort, (b) more satisfied with their leader, and (c) more effective in terms of meeting work goals (Noe, Hollenbeck, Gerhart \& Wright, 2006).

In the study of Biag, Nursing leaders contend continuously to challenges that micromanage and often thwart professional creativity. Servant leadership as an approach could address these challenges in nursing service administration. Thus, the study determined the servant leadership characterization of nursing service administrators of government hospitals in Pampanga and Tarlac. A descriptive-correlational design was used. A purposive sample of 70 nurse administrators comprised the respondents. Based on the results on Servant Leadership Inventory (SLI), the majority of them have very low to low servant first orientation, average to above average receptive responsive caring, above average other centered service, and very low to low instructive transformative relating. Their age and position were significantly related to their servant leadership disposition specifically on the 
dimensions servant first orientation and instructive transformative relating (2011).

Hale \& Fields explored the extent to which followers from Ghana and the USA have experienced three servant leadership dimensions in a work situation, and the extent to which these followers relate servant leadership dimensions to judgments about leadership effectiveness in each culture. After testing for measurement equivalence and adjusting the item weights in each culture, the researchers discovered that Ghanaians reported experiencing servant leadership behaviours significantly less than North Americans. Vision had a significantly stronger relationship with leader effectiveness for Ghanaians in comparison to North Americans, but that both sub-samples relate service and humility with leader effectiveness similarly (Hale \& Fields, 2007).

Another review deals with the historical background of servant leadership, its key characteristics, the available measurement tools, and the results of relevant studies that have been conducted so far. An overall conceptual model of servant leadership is presented. It is argued that leaders who combine their motivation to lead with a need to serve display servant leadership. Personal characteristics and culture are positioned alongside the motivational dimension. Servant leadership is demonstrated by empowering and developing people; by expressing humility, authenticity, interpersonal acceptance, and stewardship; and by providing direction. A high-quality dyadic relationship, trust, and fairness are expected to be the most important mediating processes to encourage self-actualization, positive job attitudes, performance, and a stronger organizational focus on sustainability and corporate social responsibility (Van Dierendonck, 2011).

Moreover, Mittal \& Dorfman analyzed the degree to which five aspects of servant leadership: Egalitarianism, Moral Integrity, 
Empowering, Empathy and Humility, were endorsed as important for effective leadership across cultures. While each of these dimensions was found to be associated with effective leadership, there was considerable variation in degree of endorsement of components of servant leadership across different globe culture clusters. The dimensions of Egalitarianism and Empowering were endorsed more strongly in Nordic/European cultures but less so in Asian and similar cultures. On the other hand, servant leadership dimensions of Empathy and Humility were more strongly endorsed in Asian cultures than European cultures. Further, significant relationships were found between several societal cultural values and aspects of servant leadership which help us understand why nations differ in endorsing this leadership construct (Mittal \& Dorfman, 2012).

In another study which extends the Globe study of 62 societies, it investigated an emerging model of servant leadership (SL) across cultures. SL is a holistic and altruistic approach of leadership that focuses on the commitment to serve other people. Adopting Implicit Leadership Theory's (ILT) premise that people hold cognitive categories to distinguish between prototypical leaders from non-leaders, we predicted that SL would exist in Australia and Indonesia, but its practice would be moderated by culture. Our predictions were supported, SL was perceived to be culturally universal in Australia and Indonesia. However, the different attributes perceived to make up SL were not all rated as equally important. The researchers argued that individual self-construal, socialization and national context would explain how and why culture-specific perceptions of SL exist (Pekerti \& Sendjaya, 2010).

In another article, it examined transformational leadership and servant leadership to determine what similarities and differences exist between the two leadership concepts. The authors posit that the primary difference between transformational 
leadership and servant leadership is the focus of the leader. The transformational leader's focus is directed toward the organization, and his or her behavior builds follower commitment toward organizational objectives. The leader states a vision which the employees identify with, shapes a corporate value system, and trust subordinates. On the other hand, servant leader's focus is on the followers, and the achievement of organizational objectives is a subordinate outcome. The extent to which the leader is able to shift the primary focus of leadership from the organization to the follower is the distinguishing factor in classifying leaders as either transformational or servant leaders. This article also looks at the next stage of developmental issues in servant leadership, such as the challenges facing empirical investigation and measurement, and the changes that are occurring in current thinking about the servant leadership approach. Ultimately, the case is made that although different, both transformational leadership and servant leadership offer the conceptual framework for dynamic leadership (Gregory Stone, Russell \& Patterson, 2004; Amparado, 2007).

\section{Objectives}

The study determined the Servant Leadership of School Administrators of a University, the findings served as basis for a proposed Servant Leadership Training Program.

\section{Methods}

This study was conducted in University of Cebu Lapu-Lapu and Mandaue, Mandaue City, Cebu, Philippines. The researchers measured the servant leadership of school administrators as perceived by faculty members and non-teaching staff. This study utilized the 42 items of the Servant Leadership Assessment Instrument (SLAI) by Dennis and Bocarnea (2005) to measure the extent to which a leader possessed five of these servant leader constructs using a seven-point Likert scale. The instrument also 
determined the profile of the respondents in terms of age, gender, highest educational attainment, academic rank, and length of service. Statistical treatment used were Simple percentage and Weighted Mean.

To interpret the results of the study, the following parameters were used (interpretation as suggested by Dennis and Bocarnea):
6.10-7.00 Strongly agree
5.25-6.09 Agree
4.40-5.24 Tend to agree
3.55-4.39 Neutral
2.70-3.54 Tend to disagree
1.85-2.69 Disagree
1.0-1.84 Strongly disagree

\section{Results and Discussion}

This section presents the findings of the study. Table 1 presents the profile of the respondents. Findings revealed that majority of the respondents were $21-25$ years old $(68.63 \%)$, female $(76.47 \%)$, single $(88.24 \%)$, bachelor's degree holders $(43.14 \%)$, and has served the university from $0-5$ years $(94.11 \%)$.

In table 2, the study revealed that the respondents agree (5.52) that the school administrators are exhibiting servant leadership. Out of the 42 indicators, this study shows that there are three indicators which are categorized as tend to agree: My leader is not interested in self-glorification (5.06); My leader has endured hardships, e.g. political, "turf wars," etc. to defend me (5.08); and My leader has made personal sacrifice/s for me (5.10).

The other indicators which have low means includes: My leader does not center attention on his or her own accomplishments (5.33); My leader trusts me to keep a secret 
(5.33); My leader knows I am above corruption (5.35); My leader has made sacrifices in helping others (5.37); My leader seeks to instill trust rather than fear of insecurity (5.37); My leader aspires not to be served but to serve others (5.39); My leader has asked me what I think the future direction will be (5.39).

\section{Table 1. Profile of the Respondents $(n=51)$}

\begin{tabular}{|l|c|c|}
\hline \multicolumn{1}{|c|}{ Indicators } & F & $\%$ \\
\hline Age & 35 & 68.63 \\
\hline $21-25$ & 10 & 19.61 \\
\hline $26-30$ & 4 & 7.84 \\
\hline $31-35$ & 0 & 0 \\
\hline $36-40$ & 2 & 3.92 \\
\hline $40-45$ & & \\
\hline Gender & 12 & 23.53 \\
\hline Male & 39 & 76.47 \\
\hline Female & & \\
\hline Civil Status & 45 & 88.24 \\
\hline Single & 2 & 3.92 \\
\hline Married & 4 & 7.84 \\
\hline Separated & 1 & \\
\hline Highest Educational Attainment & 2 & 1.96 \\
\hline Doctorate degree holder & 6 & 11.76 \\
\hline With units in a doctoral program & 20 & 39.22 \\
\hline Master's degree holder & 22 & 43.14 \\
\hline With units in a master's program & & \\
\hline Bachelor's degree holder & 48 & 94.11 \\
\hline Length of service & 1 & 1.96 \\
\hline 0-5 years & 1 & 1.96 \\
\hline 6-10 years & 0 & 0 \\
\hline 11-15 years & 1 & 1.96 \\
\hline 16-20 years & & \\
\hline More than 20 years & & \\
\hline & & \\
\hline
\end{tabular}


In addition, the top three indicators with the highest means were: My leader shows trustworthiness in me by being open to receive inputs from me (5.76); My leader creates a culture that fosters high standards of ethics (5.75); and My leader empowers me with opportunities so that I develop my skills (5.75).

\section{Table 2. Servant Leadership of School Administrators}

\begin{tabular}{|l|c|c|}
\hline \multicolumn{1}{|c|}{ Indicators } & Mean & Interpretation \\
\hline $\begin{array}{l}\text { 1. My leader sees serving as a } \\
\text { mission of responsibility to others. }\end{array}$ & 5.69 & Agree \\
\hline $\begin{array}{l}\text { 2. My leader is genuinely interested } \\
\text { in me as a person. }\end{array}$ & 5.63 & Agree \\
\hline $\begin{array}{l}\text { 3. My leader trusts me to keep a } \\
\text { secret. }\end{array}$ & 5.33 & Agree \\
\hline $\begin{array}{l}\text { 4. My leader models service to } \\
\text { inspire others. }\end{array}$ & 5.55 & Agree \\
\hline $\begin{array}{l}\text { 5. My leader has shown unselfish } \\
\text { regard for my well-being. }\end{array}$ & 5.57 & Agree \\
\hline $\begin{array}{l}\text { 6. My leader desires to develop my } \\
\text { leadership potential. }\end{array}$ & 5.71 & Agree \\
\hline $\begin{array}{l}\text { 7. My leader creates a culture that } \\
\text { fosters high standards of ethics. }\end{array}$ & 5.75 & Agree \\
\hline $\begin{array}{l}\text { 8. My leader talks more about } \\
\text { employees' accomplishments than } \\
\text { his or her own. }\end{array}$ & 5.43 & Agree \\
\hline $\begin{array}{l}\text { 9. My leader has endured hardships, } \\
\text { e.g. political, "turf wars," etc. to } \\
\text { defend me. }\end{array}$ & 5.08 & Tend to agree \\
\hline $\begin{array}{l}\text { 10. My leader shows trustworthiness } \\
\text { in me by being open to receive inputs } \\
\text { from me. }\end{array}$ & 5.76 & Agree \\
\hline 11. My leader lets me make decisions & 5.71 & Agree \\
\hline
\end{tabular}




\begin{tabular}{|c|c|c|}
\hline with increasing responsibility. & & \\
\hline $\begin{array}{l}\text { 12. My leader does not overestimate } \\
\text { his or her merits. }\end{array}$ & 5.49 & Agree \\
\hline $\begin{array}{l}\text { 13. The level of trust my leader } \\
\text { places in me increases my } \\
\text { commitment to the organization. }\end{array}$ & 5.53 & Agree \\
\hline $\begin{array}{l}\text { 14. My leader has sought my vision } \\
\text { regarding the organization's vision. }\end{array}$ & 5.55 & Agree \\
\hline $\begin{array}{l}\text { 15. My leader understands that } \\
\text { serving others is most important. }\end{array}$ & 5.63 & Agree \\
\hline $\begin{array}{l}\text { 16. My leader voluntarily gives of him } \\
\text { or herself, expecting nothing in } \\
\text { return. }\end{array}$ & 5.51 & Agree \\
\hline $\begin{array}{l}\text { 17. My leader has shown his or her } \\
\text { care for me by encouraging me. }\end{array}$ & 5.67 & Agree \\
\hline $\begin{array}{l}\text { 18. My leader gives of themselves } \\
\text { with no ulterior motives. }\end{array}$ & 5.47 & Agree \\
\hline $\begin{array}{l}\text { 19. My leader has shown } \\
\text { compassion in their actions toward } \\
\text { me. }\end{array}$ & 5.53 & Agree \\
\hline $\begin{array}{l}\text { 20. My leader is not interested in } \\
\text { self-glorification. }\end{array}$ & 5.06 & Tend to agree \\
\hline $\begin{array}{l}\text { 21. My leader makes me feel } \\
\text { important. }\end{array}$ & 5.65 & Agree \\
\hline $\begin{array}{l}\text { 22. My leader is humble enough to } \\
\text { consult others in the organization } \\
\text { when they may not have all the } \\
\text { answers. }\end{array}$ & 5.45 & Agree \\
\hline $\begin{array}{l}\text { 23. My leader has made personal } \\
\text { sacrifice/s for me. }\end{array}$ & 5.10 & Tend to agree \\
\hline $\begin{array}{l}\text { 24. My leader gives me the authority I } \\
\text { need to do my job }\end{array}$ & 5.65 & Agree \\
\hline $\begin{array}{l}\text { 25. My leader turns over some } \\
\text { control to me so that I may accept }\end{array}$ & 5.53 & Agree \\
\hline
\end{tabular}




\begin{tabular}{|l|c|c|}
\hline more responsibility. & & \\
\hline $\begin{array}{l}\text { 26. My leader has made sacrifices in } \\
\text { helping others. }\end{array}$ & 5.37 & Agree \\
\hline 27. My leader shows concern for me. & 5.57 & Agree \\
\hline $\begin{array}{l}\text { 28. My leader empowers me with } \\
\text { opportunities so that I develop my } \\
\text { skills. }\end{array}$ & 5.75 & Agree \\
\hline $\begin{array}{l}\text { 29. My leader understands that } \\
\text { service is the core of leadership. }\end{array}$ & 5.73 & Agree \\
\hline $\begin{array}{l}\text { 30. My leader communicates trust to } \\
\text { me. }\end{array}$ & 5.57 & Agree \\
\hline $\begin{array}{l}\text { 31. My leader seeks to instill trust } \\
\text { rather than fear of insecurity. }\end{array}$ & 5.37 & Agree \\
\hline $\begin{array}{l}\text { 32. My leader has encouraged me to } \\
\text { participate in determining and } \\
\text { developing a shared vision. }\end{array}$ & 5.55 & Agree \\
\hline $\begin{array}{l}\text { 33. My leader entrusts me to make } \\
\text { decisions. }\end{array}$ & 5.71 & Agree \\
\hline $\begin{array}{l}\text { 34. My leader and I have written a } \\
\text { clear and concise vision statement. }\end{array}$ & 5.51 & Agree \\
\hline $\begin{array}{l}\text { 35. My leader aspires not to be } \\
\text { served but to serve others. }\end{array}$ & 5.39 & Agree \\
\hline $\begin{array}{l}\text { 36. My leader has asked me what I } \\
\text { think the future direction will be. }\end{array}$ & 5.39 & Agree \\
\hline $\begin{array}{l}\text { 37. My leader does not center } \\
\text { attention on his or her own } \\
\text { accomplishments. }\end{array}$ & 5.33 & Agree \\
\hline $\begin{array}{l}\text { 38. My leader models service in his } \\
\text { or her behaviors, attitudes, or values. }\end{array}$ & 5.41 & Agree \\
\hline $\begin{array}{l}\text { 39. My leader's demeanors are one's } \\
\text { of humility. }\end{array}$ & 5.53 & Agree \\
\hline $\begin{array}{l}\text { 40. My leader has shown that they } \\
\text { want to employees' vision into the } \\
\text { organization's goals and objectives. }\end{array}$ & 5.63 & Agree \\
\hline
\end{tabular}




\begin{tabular}{|l|c|c|}
\hline $\begin{array}{l}\text { 41. My leader knows I am above } \\
\text { corruption. }\end{array}$ & 5.35 & Agree \\
\hline $\begin{array}{l}\text { 42. My leader seeks my commitment } \\
\text { concerning the shared vision of the } \\
\text { organization. }\end{array}$ & 5.63 & Agree \\
\hline Grand Mean & 5.52 & Agree \\
\hline
\end{tabular}

\section{Conclusion}

Based on the findings of the study, the respondents agree that the school administrators of the university exhibit servant leadership. However, the servant leadership characteristics of the school heads and directors may be improved through lectures and trainings.

\section{Literature Cited}

Amparado, M. A. P. (2007). Transformational and Transactional Leadership Styles of the Nursing Student Leaders:

Enhanced Leadership Training Program. Paper presented at the $10^{\text {th }}$ East Asian Forum of Nursing Scholars and the Asian Journal of Nursing, Silliman University, Dumaguete City, Negros Oriental, Philippines, 10(1), 68, 2007, Available at SSRN: https://ssrn.com/abstract=3654238.

Biag, A. D. (2011). Servant Leadership in Nursing Service Administration: The Case of Government Hospitals in Pampanga and Tarlac. Philippine Journal of Nursing, Vol. 81 (2), ISSN 0048-33818, pp. 12-19.

Dennis, R. S., \& Bocarnea, M. (2005). Development of the servant leadership assessment instrument. Leadership \& organization development journal, 26 (8), 600-615.

Gregory Stone, A., Russell, R. F., \& Patterson, K. (2004). 
Transformational versus servant leadership: A difference in leader focus. Leadership \& Organization Development Journal, 25(4), 349-361.

Hale, J. R., \& Fields, D. L. (2007). Exploring servant leadership across cultures: A study of followers in Ghana and the USA. Leadership, 3(4), 397-417.

Mittal, R., \& Dorfman, P. W. (2012). Servant leadership across cultures. Journal of World Business, 47 (4), 555-570.

Newstrom, J. W. (2007). Organizational Behavior: Human Behavior at Work. $12^{\text {th }}$ edition. Singapore: Mc-Graw Hill Education (Asia).

Noe, R. A., Hollenbeck, J. R., Gerhart, B. \& Wright, P. M. (2006). Human Resource Management: Gaining a Competitive Advantage. $5^{\text {th }}$ edition. Singapore: Mc-Graw Hill Education (Asia)

Pekerti, A. A., \& Sendjaya, S. (2010). Exploring servant leadership across cultures: comparative study in Australia and Indonesia. The International Journal of Human Resource Management, 21(5), 754-780.

Robbins, S. P. \& Coulter, M. (2001). Management. $6^{\text {th }}$ edition. Singapore: Pearson Education Asia Pte. Ltd.

Van Dierendonck, D. (2011). Servant leadership: A review and synthesis. Journal of Management, 37(4), 1228-1261. 